\title{
Working
}

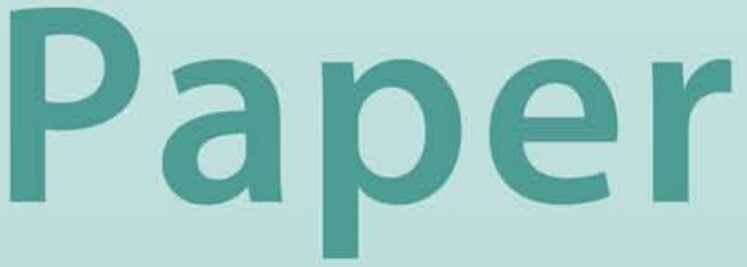




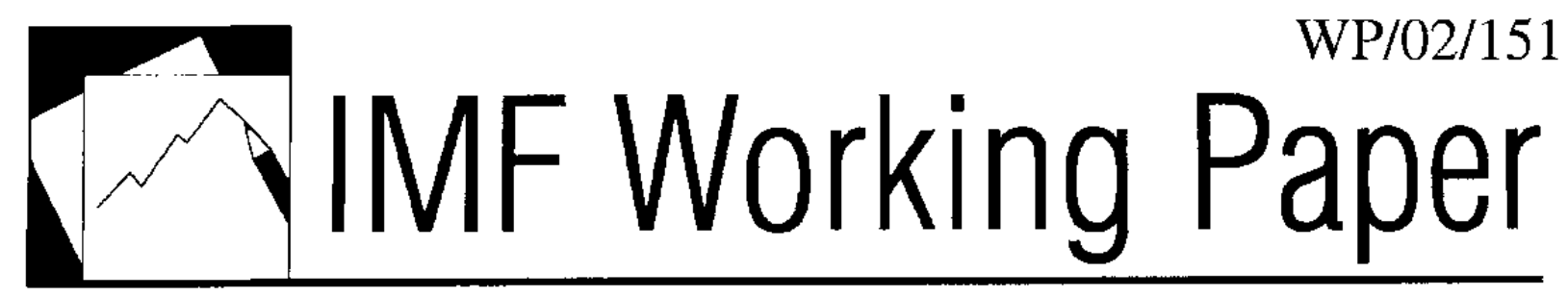

Wage Moderation in France

Marcello Estevão and Nigar Nargis 


\title{
IMF Working Paper
}

\author{
European I Department
}

\section{Wage Moderation in France}

\author{
Prepared by Marcello Estevão and Nigar Nargis ${ }^{1}$ \\ Authorized for distribution by Robert Ford
}

September 2002

\begin{abstract}
The views expressed in this Working Paper are those of the author(s) and do not necessarily represent those of the IMF or IMF policy. Working Papers describe research in progress by the author(s) and are published to elicit comments and to further debate.

Using household level data for France from 1990 to 2000, we estimate a relationship between wages and unemployment taking into account compositional, time and regional effects. We show that this relationship shifted outward during the 1990's most likely because of a structural change in worker' behavior, i.e. "wage moderation." The outward shift was particularly large between 1996 and 2000 and undoubtedly contributed strongly to the exceptional employment performance during that period.
\end{abstract}

JEL Classification Numbers: D2,E2, J23

Keywords: Employmnet, wages, bargaining, structural change, labor market

Author's E-Mail Address:mestevao@imf.org and nn29@corncll.edu

${ }^{1}$ Authors are, respectively, from the European I Department of the IMF and Cornell University. The authors greatly benefited from insightful discussions with Luc Everaert and Robert Ford. J.S. Butlar, Jörg Decressiin, Antonio Splimbergo, and seminar participants at the IMF gave valuable suggestions. Didier Blanchet answered numerous data questions. All errors and omissions should be attributed solely to the authors. 


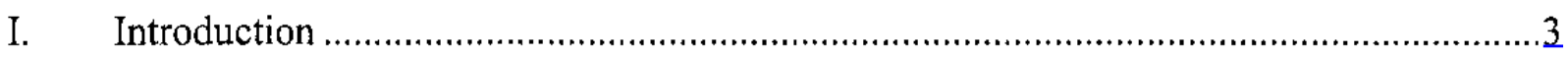

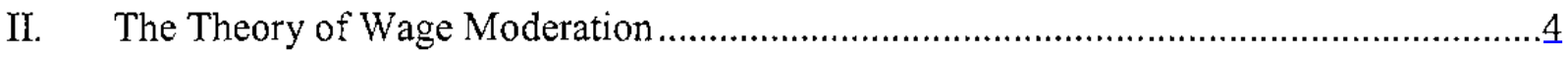

III. French Labor Market Performance in the 1990s .........................................................

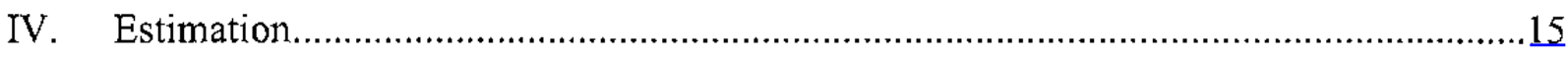

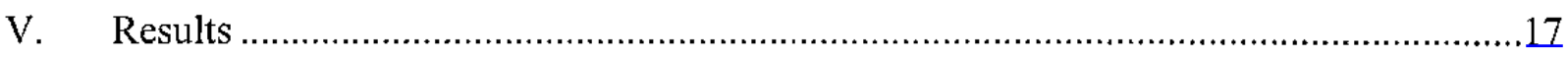

VI. Empirical Evidence of Wage Moderation in France .....................................................20

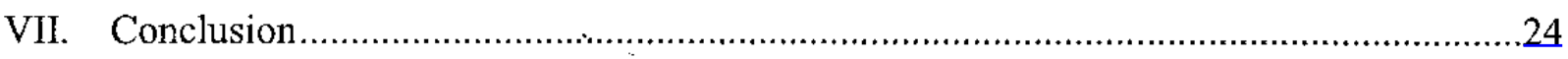

Text Tables

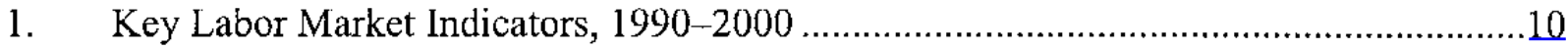

2. Parameter Estimates from the Hourly Wage Regression .............................................18

3. Parameter Estimates from the Annual Earnings Regression.......................................19

4. Estimates of the Dynamic Specification …………...............................................20

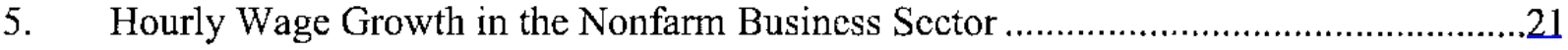

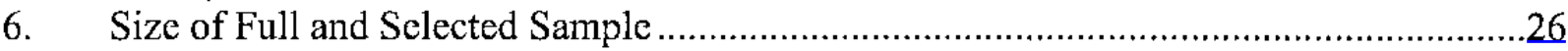

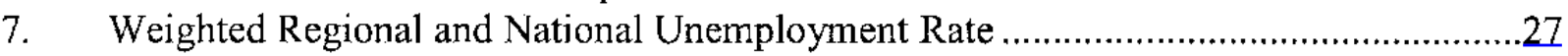

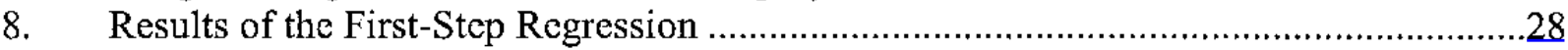

\section{Text Figures}

1. Employment and Unemployment Rates by Gender and Age Groups ...........................11

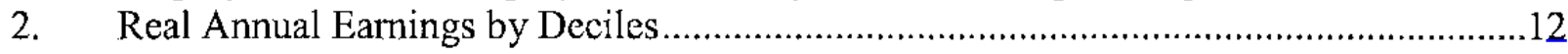

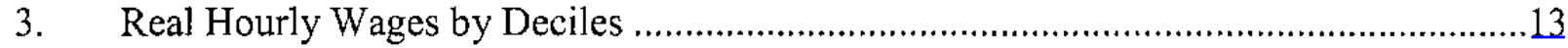

4. Employment Growth by Wage Deciles......................................................................14

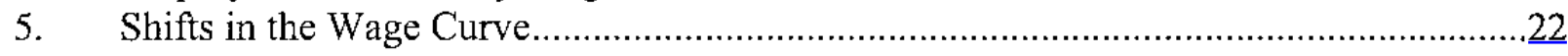

6. Labor Share and Replacement Rates........................................................................23

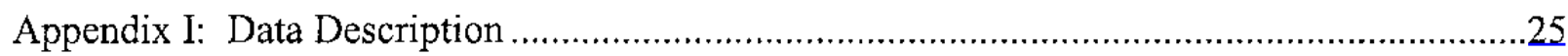

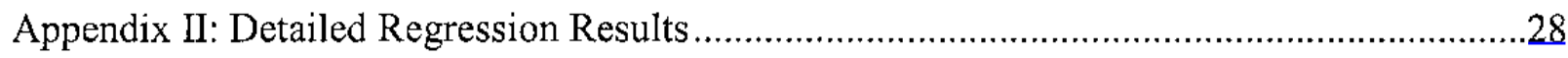

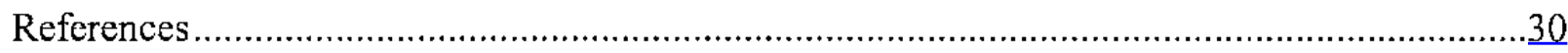




\section{INTRODUCTION}

Wage moderation is often defined as the shortfall in growth in the average wage relative to the growth in overall productivity. Moderate wage growth is of interest to a macro-labor economic analyst in that it induces firms to hire more employees relative to capital, which increases their profitability, raises employment, and in turn reduces unemployment. The notion of wage moderation has, however, remained far from being explicitly defined in the literature. This concept has recently been used in Blanchard (2000) in the framework of an economy with a balanced growth path. In his model, wage moderation is defined as the decline in the real product wage adjusted for the level of technology, or the wage in efficiency units.

The history of wage moderation goes back to the mid-1980s, when some European countries succeeded in reversing the upward trend in the unemployment rate observed since the late 1960s. The Netherlands and Ireland were the first two countries to experience sharp declines in unemployment, to be followed by some other European countries, such as France, Spain, Italy, and Germany, by the late1990s. Wage moderation, along with changes in labor market policies and structural conditions, is believed to have played a major role in reversing the persistent upward trend in the unemployment rate in these countries. As pointed out in Blanchard (2000), this evolution in wages and unemployment in several European countries could be attributed to a decrease in the bargaining power of workers since the mid-1980s.

The aim of this paper is primarily to investigate wage moderation in France with an added focus on the supply side of the French labor market. We base the analysis on individual level information that can help to disentangle the origin of shifts in the preference of workers between work and leisure. Wage moderation, in this framework, is defined as an increase in workers' preference for employment or an overall reduction in unions' bargaining power. We aggregate the information derived from individual units to find empirical evidence in support of the macroeconomic phenomenon of wage moderation. As such, it is the first attempt to use micro foundations in analyzing wage moderation in an economy.

The prima facie evidence of wage moderation in France is found in the slowdown of wage growth in the 1990s in contrast with the well-documented large wage increases during the late $1970 \mathrm{~s}$ and the first half of the $1980 \mathrm{~s}^{2}$ As it will be shown in the body of this paper, once the effects of changes in the composition of the labor force and variations in the unemployment rate are taken into account, real hourly wages grew much less than productivity throughout the $1990 \mathrm{~s}$. This result is all the more notable given the adverse effect on take-home pay of the increase in income tax rates throughout the decade (despite the recent cuts). Also, changes in unemployment benefits replacement rates, intensity of labor in the production process, and labor market regulations do not seem to explain the wage behavior in this period.

${ }^{2}$ See Blanchard (1997) and Decressin and others (2001). 
In this paper, we define wage moderation in an explicit theoretical framework based on the bargaining models described in Layard and others (1991). As an empirical counterpart, we present an econometric model of wage detcrmination. The estimates from this model are used to construct a "wage curve" in which individual pay is linked to the local unemployment rate controlling for observable individual characteristics, a paradigm set by Blanchflower and Oswald (1994). The shifts in this curve provide the basis for the assessment of the role of wage moderation in reducing unemployment in France. The data come from the Enquete Emploi, a French household level employment survey. The econometric exercise points to a significant degree of wage moderation during the $1990 \mathrm{~s}$, consistent with a decline in labor union bargaining power or a greater preference for employment over wages.

The paper is organized in the following sections. Section II conceptualizes wage moderation in the theoretical bargaining framework. Section III provides some stylized facts of French labor market developments in the 1990s in support of the conjecture of wage moderation. Section IV lays out the econometric models. The results from estimation are presented in Section V. Section VI uses these results to assess aggregate wage moderation. The paper concludes with Section VII.

\section{The Theory of Wage Moderation}

Most workers in continental Europe receive wages set by collective agreements negotiated between trade unions and employers, in contrast to the more competitive wage setting prevailing in the United States. This does not necessarily imply that the percentage of trade union members among all wage/salary earners is large, since unions may negotiate pay on behalf of the employees irrespective of their affiliation with the unions. France is a case in point. With about 10 percent union membership, which is one of the lowest among continental European OECD countries, more than 70 percent of all employees in France are covered by collective bargaining.

A weakening of bargaining power of the trade unions is expected to translate into slack wage growth for most of the employees in France. So, modeling wage moderation in the French labor market would require a collective bargaining framework at the firm level, as opposed to the traditional neoclassical model. We consider the standard right-to-manage model which postulates that firms and unions bargain over wages but firms set employment unilaterally. ${ }^{3}$ Firms are assumed to determine employment by maximizing short-run profits given the negotiated wages and the stock of capital. ${ }^{4}$ On the other hand, unions take into consideration the employment effects when negotiating the wage. The profit maximization problem of firm $i$ is, then:

\footnotetext{
${ }^{3}$ This model is formally equivalent to the basic framework discussed in Layard and others (1991).

${ }^{4}$ The assumption of capital exogeneity determines the short-run character of the model in which an analysis of the optimal long-run growth path is irrelevant. Nickell and Layard (1997) and Daveri and Tabellini (2000) have focused somewhat on the relationship between the equilibrium unemployment rate and the optimal rate of capital accumulation. They introduced a negative relationship between the growth rate of per capita capital and the equilibrium unemployment rate through the utilization of an overlapping
} 


$$
\begin{aligned}
& \underset{N_{i}}{\operatorname{Max}} \Pi_{i}=P\left(Y_{i}^{d}\right) Y_{i}-W_{i}\left(1+t^{e}\right) N_{i} \\
& \text { s.t. } Y_{i}=T_{i} K_{i}^{\alpha} N_{i}^{1-\alpha} \\
& Y_{i}^{d}=\left(\frac{P}{P_{i}}\right)^{\varepsilon}, \varepsilon>1 \\
& Y_{i}^{d}=Y_{i},
\end{aligned}
$$

where $W_{i}, P_{i}, P, N_{i}, T_{i}, K_{i} t^{e}$, and $\varepsilon$ represent, respectively, the bargained wage, firm-level price, economy-wide average price level, employment at the firm, total factor productivity, capital, the payroll tax rate paid by the firm, and the absolute value of the price elasticity of demand. The production function is assumed to be Cobb-Douglas in (1a), the demand for output is a function of its relative price with the aggregate price level taken as exogenous in (1b), and there are no costs to adjust labor to its optimal value. Solving this maximization problem and using the assumption that firms are identical-implying that the subscript $i$ can be dropped for all the variables in the first order condition of (1)-firms' optimal demand for labor is

$$
N=\left(\frac{W\left(1+t^{e}\right)}{P} \frac{\varepsilon}{(\varepsilon-1)(1-\alpha)}\left(T K^{\alpha}\right)^{\frac{1-\varepsilon}{\varepsilon}}\right)^{\frac{\varepsilon}{\alpha(1-\varepsilon)-1}} .
$$

Note that the elasticities of labor demand to exogenous changes in the negotiated wages or in social security taxes, $\varepsilon_{N W}$, and the share of labor costs in profits, $\lambda$ - to be used belowdepend only on the demand elasticity, $\varepsilon$, and on the labor intensity of production, $(1-\alpha)$.

The bargaining problem can be described as the maximization of a Nash function subject to this labor demand function:

$$
\underset{W}{\operatorname{Max}} \Omega=\left[N^{\gamma}\left(\frac{W}{C}-A\right)\right]^{\theta} \Pi
$$

s.t. $N=N(W)$, from firm's profit maximization,

where $N, W$, and $A$ represent, respectively, employment, wage, and profits for a firm. $\theta$ measures workers' relative bargaining power and $\gamma$ indicates how much unions care about employment. $C$ is the consumer price index adjusted for the fiscal wedge between earned wages and workers' take-

generations framework. However, this paper focuses on estimations of a curve relating wages to unemployment. 
home pay. Defining $P_{C}$ as the net-of-tax consumer price index, $t^{c}$ as the consumption tax rate, $t^{d}$ as the income tax rate, and $t^{s s}$ as the social security tax rate, $C$ can be written as

$$
C=P_{C}\left[\frac{1+t^{c}}{\left(1-t^{d}\right)\left(1-t^{s i x}\right)}\right] .
$$

$A$ represents workers' outside opportunities, which are assumed to be the same for every worker in the economy, and can be written as

$$
A=(1-u) \frac{W}{C}+u \frac{B}{C_{U}},
$$

where $u, W, B$, and $C_{U}$ are the unemployment rate, aggregate wages, worker's income when unemployed, and the consumer price index adjusted for the fiscal wedge on the income received when unemployed. The unemployment rate is a proxy for the probability of finding work elsewhere in case of disagreement during the bargaining process.

The first-order condition of this bargaining problem yields:

or

$$
\frac{\theta \gamma\left(\frac{W}{C}-A\right) \varepsilon_{N W}+\frac{W}{C}}{\frac{W}{C}-A}=\lambda
$$

where $m=\frac{\theta \gamma \varepsilon_{N W}-\lambda}{1+\theta \gamma \varepsilon_{N W}-\lambda}=m\left(\theta, \gamma, \lambda(\varepsilon, \alpha), \varepsilon_{N W}(\varepsilon, \alpha)\right)$

In words, real wages corrected for the tax wedge are a markup over workers' aiternative income. This markup is higher when workers' bargaining power is stronger, when the demand for output and the demand for labor are less elastic, when the labor intensity of production is less, and when unions care less about the level of employment. Using the formula for $A$ as in equation (5) yiclds a wage locus,

$$
W=\frac{m u}{1-m(1-u)} B \frac{C}{C_{U}}
$$

Equations (2) and (8) determine equilibrium in the labor market for a given size of the labor force. Wages are higher when the ratio between the fiscal wedge on labor income and the fiscal wedge on unemployment benefits is larger. So, to the extent that employed and unemployed individuals pay the same consumption price including taxes, indirect taxation (and the level of consumer prices) cancels out. If it were available, the tax-adjusted unemployment income would be the right "deflator" for wages in the estimation of the wage/unemployment locus described in 
(8). In its absence, nominal hourly wages should be corrected for inflation, technological growth and all other variables that affect the alternative income of a worker if unemployed. ${ }^{5}$

The relationship between wages and unemployment as generated in equation (8) can be summarized as:

$$
\frac{W}{B} * \tau=f(m, u), f_{m}>0 \text { and } f_{u}<0,
$$

where, $W, B$ and $\tau$ stand for the hourly wage, the income a worker would receive if unemployed, and the tax wedge between labor income and unemployment income; $m$, as defined in equation (7) by $m\left(0, \gamma, \lambda(\varepsilon, \alpha), \varepsilon_{N W}(\varepsilon, \alpha)\right)$, is a composite structural parameter determining the position of the wage curve and its steepness; and $u$ is the unemployment rate.

For a given rate of unemployment, wages will depend on how large the unemployment income (corrected for its relative tax liabilities) is and on the position of the wage curve, a function of $m$. Ceteris paribus, the larger the unemployment income the bolder will be wage demands because in case of disagreement during the bargaining process the alternative scenario of being unemployed becomes less unattractive. When the unemployment rate increases, the probability of not finding a job also increases and wage demands will be more subdued. Whenever unions' bargaining power becomes weaker ( $\theta$ is larger), or whenever unions give more value to employment levels vis-à-vis higher wages ( $\gamma$ is larger), the parameter $m$ decreases and wages will be lower for a given rate of uncmployment.

Changes in production technology and product market conditions may also affect the relationship between wages and unemployment through variations in the other parameters in $m .^{6}$ If technology is more labor intensive, such that $(1-\alpha)$ is higher, wage demands will be weaker because workers will incorporate the stronger effect of higher wages on employment. This would be reflected in lower share of labor costs in profits $(\lambda)$, or higher elasticity of labor demand to exogenous changes in the negotiated wages or in social security taxes $\left(\varepsilon_{N W}\right)$, or both. The same argument holds if the elasticity of product demand $(\varepsilon)$ is larger.

Wage moderation is defined in this model as a decline in union's bargaining power or a greater preference for employment, which would cause a decrease in the markup (m) of wages over workers' alternative income and thus a downward shift in the wage setting equation. So, for example, reductions in equilibrium wages caused by the lowering of labor income taxes are not

${ }^{5}$ Blanchard and Katz (1997) enumerate the variables that might affect an individual's income when unemployed and pay particular attention to the importance of technological growth.

${ }^{6}$ Alternative models postulating that firms and workers bargain over wages and employment ("efficient bargaining models") would suggest that only workers' preferences and relative bargaining power affect the parameter $m$. But the right-to-manage model seems to be a more realistic rendition of how wage bargaining takes place in practice. 
interpreted as wage moderation. Wage moderation is also reflected in the change in the sensitivity of wages to the unemployment rate. ${ }^{7}$ It follows that, in order to isolate the contribution of $\theta$ and $\gamma$ - the wage moderation parameters in equation (9) - it is necessary to control for the effects of the income a worker would receive if unemployed (B), the tax wedge between labor income and unemployment income $(\tau)$, technological change $(\alpha)$, and the elasticity of product market demand $(\varepsilon)$. As a prelude to the empirical identification of wage moderation in France in the late 1990s, we turn to a portrayal of its labor market performance.

\section{French Labor Market Performance in the 1990s}

The French economy grew robustly between 1997 and 2000, without signs of price acceleration. Labor market performance was also quite strong, with harmonized unemployment rates falling from 121/4 percent in mid-1997 to 81/2 percent in May 2001. Employment rose particularly sharply during the same period with a yearly average of 400,000 additional jobs, substantially more than the 1987-89 expansion, when average annual employment increased by 270,000. Taking into account that average output growth between 1997 and 2000 was 0.8 percentage point below the average growth at the end of the $1980 \mathrm{~s}$ - and assuming the same growth in labor productivity - the recent recovery should have produced about 100,000 fewer jobs than the previous one. As discussed in Pisani-Ferry (2000), part of this difference can be explained by a change in the thrust of government policies toward reducing unemployment rates mainly among less-skilled workers. ${ }^{8}$ However, given current estimates for these effects, about half of the better employment performance in the latter period remains unexplained.

A compilation of data from the Enquête Emploi shows that unemployment rates have declined steadily since the 1997 peak (Table 1). By 2000, the proportion of the population between 15 and 64 years of age that is employed-the employment rate-reached 61 percent, the largest value in the decade, albeit still low by international standards. ${ }^{9}$ The proportion of full-time workers in total employment declined from 87 percent in 1990 to 82 percent in 2000 , due to increased acceptance of part-time arrangements. Average hours of work per week also declined

${ }^{7}$ The nonlinearity of wage in $m$ and $u$ in equation (8) indicates this interaction.

${ }^{8}$ Pisani-Ferry (2000) provides an overview of all the studies measuring the effect of recent government policies on employment. His analysis is limited to the period going from 1997 to 1999 but an update of the table shown in page 29 of his report would result in similar conclusions for annual averages from 1997 to 2000. Among the most important policy changes are the cuts in social security contributions for firms hiring low-wage earners since 1993 and the three laws aiming at the reduction of the standard workweek to 35 hours enacted after 1996.

${ }^{9}$ See OECD (2001). For instance, employment rates in Germany (66.3 percent), the United States (74.1 percent) and the Netherlands (72.9 percent) were much larger than in France. Italy (53.4 percent) and Spain (56.1 percent) continue to trail France. The OECD average was 65.7 percent. 
steadily throughout the decade. The two largest annual declines in average hours of work occurred in 1999 and 2000 even as economic activity expanded vigorously, reflecting the various workweek reduction laws introduced since 1996. A breakdown of employment by gender shows slightly larger growth in the employment rate among women since 1994 (Figure 1). Youth employment increased appreciably over 1997-2000 and the employment rate for this group edged up after hitting a trough in 1997. The reduction in the unemployment rate has been larger among younger workers than prime working-age and older individuals.

More important for this paper, real hourly wages increased 6 percent during 1990-2000 (an average annual rate of 0.5 percent), which is much below the total factor productivity growth in France adjusted for the labor share (about 1.4 percent a year), a measure of labor augmenting technical progress. ${ }^{10}$ Furthermore, most of this growth ( 5 percentage points) occurred during 1990-93. This latter observation is associated with a contemporary change in the composition of the labor force in France: the recession years pushed less-skilled workers (and, thus, low-wage earners) out of the labor market, raising average wages. The growth rate of real hourly wages fell below the trend growth rate of total factor productivity during the recovery from 1994 onward. Real annual earnings increased at an even lower rate than real hourly wages throughout the decade.

The distribution of wage and earnings growth has, however, not been uniform across deciles. ${ }^{11}$ The bottom deciles of the earnings distribution experienced less growth than the upper deciles over the entire sample period (Figure 2). However, there was a greater increase in the lower deciles during the high-growth period (1997-2000). Unlike total labor earnings, growth in hourly wages at lower deciles was stronger during the 1990s (Figure 3). Underlying this difference was a stronger negative trend in average hours of work among less-skilled individuals throughout the decade. Changes in hourly wages over the different stages of the business cycle point to even larger increases in real hourly wages of less-skilled workers during the high-growth period. A breakdown in employment growth by wage deciles also suggests important composition changes (Figure 4). In particular, employment growth during the decade was stronger in lower wage deciles. The larger growth of real hourly wages and employment at the lower tail of the wage distribution is consistent with a change in regime in the 1990s toward an expansion of labor demand for less-skilled workers--a stated objective of government policies implemented through several cuts in employers' social security contributions. The implied result is diminishing wage dispersion in France, mainly since 1997.

${ }^{10}$ Technological progress is assumed to be labor augmenting (Harrod neutral) to allow for balanced growth in a dynamic setup. The measure proposed here is a proxy for this variable and has also been used in Blanchard (1997).

${ }^{11}$ Earning and hourly wage are assumed to have log normal distributions. 
The development of these key labor market variables points to the importance of using microcconomic data to analyze the role of wage moderation. In particular, there appear to have been significant changes in the composition of work hours and worker quality in the $1990 \mathrm{~s}$.

Table 1. Key Labor Market Indicators, 1990-2000 (Weighted means and standard errors ${ }^{1}$ )

\begin{tabular}{|c|c|c|c|c|c|c|}
\hline Year & $\begin{array}{c}\text { Real } \\
\text { Annual } \\
\text { Earning }\end{array}$ & $\begin{array}{c}\text { Real } \\
\text { Hourly } \\
\text { Wagc }^{2}\end{array}$ & $\begin{array}{c}\text { Weekly } \\
\text { Ilours } \\
\text { Worked }\end{array}$ & $\begin{array}{c}\text { Employment } \\
\text { Rate (\%) }\end{array}$ & $\begin{array}{c}\text { Full Time } \\
\text { Employed } \\
\text { Rate (\%) }\end{array}$ & $\begin{array}{c}\text { Unemployment } \\
\text { Rate (\%) }\end{array}$ \\
\hline 1990 & 87982.54 & 41.48 & 39.94 & 59.92 & 87.08 & 9.24 \\
& $(288.08)$ & $(0.16)$ & $(12.28)$ & $(0.15)$ & $(0.14)$ & $(0.11)$ \\
\hline 1991 & 89007.05 & 42.00 & 40.38 & 59.94 & 86.94 & 9.11 \\
& $(308.03)$ & $(0.16)$ & $(12.51)$ & $(0.15)$ & $(0.14)$ & $(0.11)$ \\
\hline 1992 & 90388.80 & 42.60 & 40.17 & 59.96 & 86.29 & 10.12 \\
& $(307.57)$ & $(0.16)$ & $(12.36)$ & $(0.15)$ & $(0.14)$ & $(0.11)$ \\
\hline 1993 & 91921.23 & 44.16 & 39.965 & 59.02 & 85.00 & 11.21 \\
& $(319.30)$ & $(0.17)$ & $(12.62)$ & $(0.14)$ & $(0.14)$ & $(0.11)$ \\
\hline 1994 & 89466.60 & 43.44 & 39.958 & 58.26 & 83.99 & 12.47 \\
& $(319.35)$ & $(0.22)$ & $(12.91)$ & $(0.14)$ & $(0.15)$ & $(0.12)$ \\
\hline 1995 & 88546.88 & 42.66 & 39.683 & 59.01 & 83.2 & 11.67 \\
& $(318.00)$ & $(0.17)$ & $(12.79)$ & $(0.14)$ & $(0.15)$ & $(0.11)$ \\
\hline 1996 & 87837.75 & 41.93 & 39.600 & 59.17 & 82.59 & 12.18 \\
& $(323.04)$ & $(0.17)$ & $(12.74)$ & $(0.14)$ & $(0.15)$ & $(0.12)$ \\
\hline 1997 & 88418.46 & 42.01 & 39.211 & 58.81 & 82.01 & 12.38 \\
& $(336.04)$ & $(0.18)$ & $(12.95)$ & $(0.14)$ & $(0.16)$ & $(0.12)$ \\
\hline 1998 & 88614.96 & 42.58 & 39.348 & 59.38 & 81.59 & 11.90 \\
& $(334.57)$ & $(0.19)$ & $(12.75)$ & $(0.14)$ & $(0.16)$ & $(0.12)$ \\
\hline 1999 & 88353.71 & 42.85 & 38.881 & 59.80 & 81.87 & 11.82 \\
& $(326.29)$ & $(0.20)$ & $(12.38)$ & $(0.14)$ & $(0.16)$ & $(0.11)$ \\
\hline 2000 & 87435.73 & 42.80 & 38.469 & 61.14 & 82.44 & 10.09 \\
& $(326.91)$ & $(0.35)$ & $(12.30)$ & $(0.14)$ & $(0.15)$ & $(0.11)$ \\
\hline
\end{tabular}

Sources: INSEE, Enquête Emploi; and authors' estimates.

${ }^{1}$ The means and standard errors are weighted by individual sampling weights. The standard errors are in parentheses.

${ }^{2}$ Real earnings and wages in 1990 francs were obtained by deflating the respective nominal variables by the consumer price index (CPI) for France. 
Figure 1. Employment and Unemployment Rates by Gender and Age Groups

(Percent)

Employment Rate by Gender

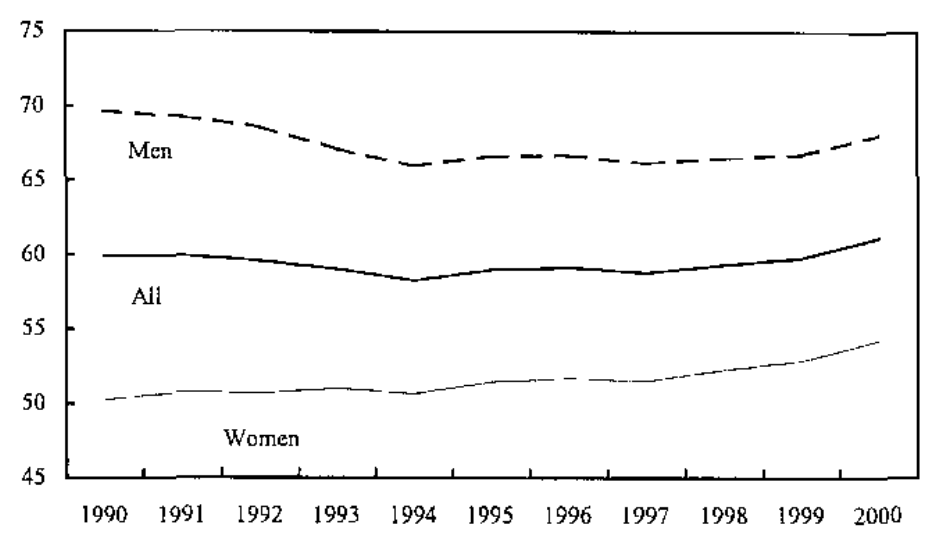

Uncmployment Rate by Gender

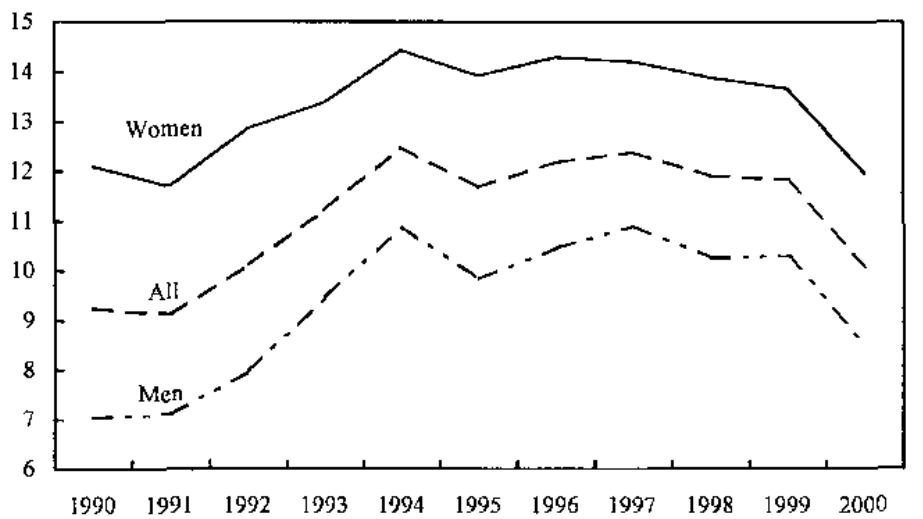

Employment Rate by Age Group

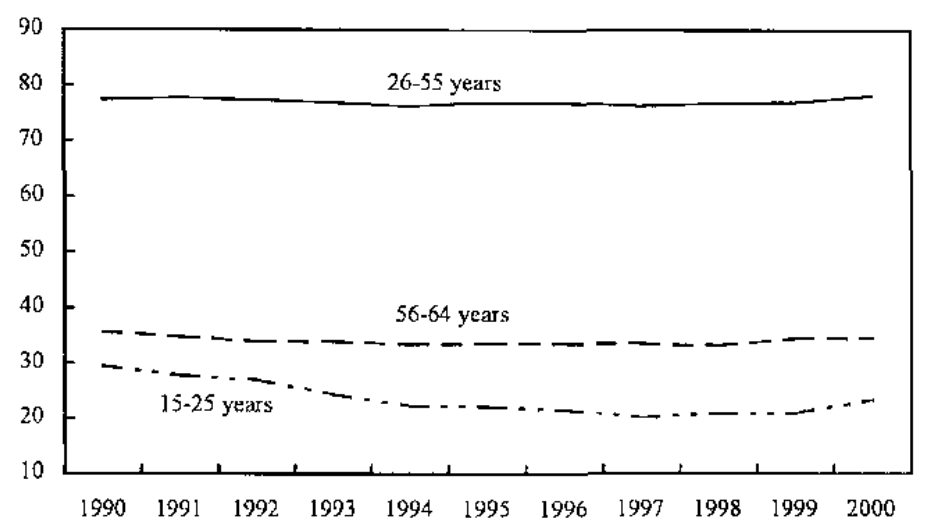

Unemployment Rate by Age Group

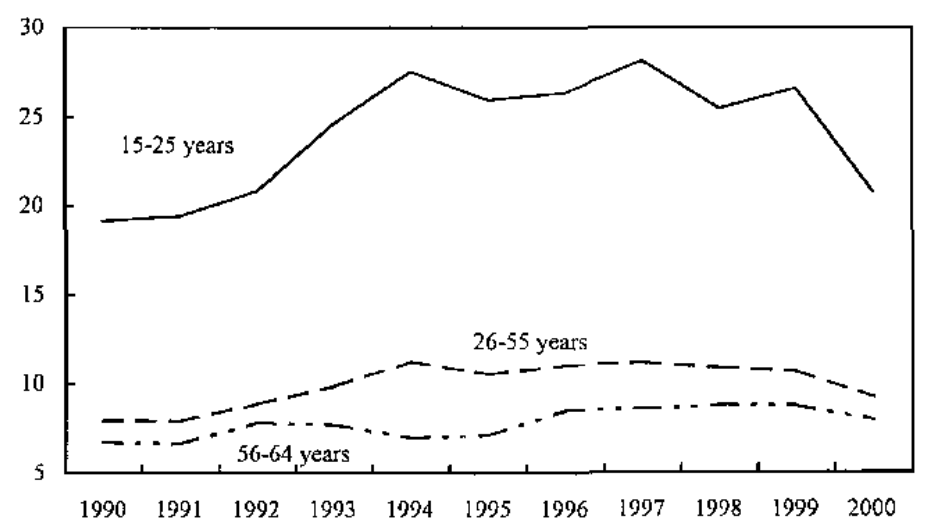

Sources: INSEE, Enquête Emploi; and authors' calculations. 
Figure 2. Real Annual Earnings by Deciles (Percent change)
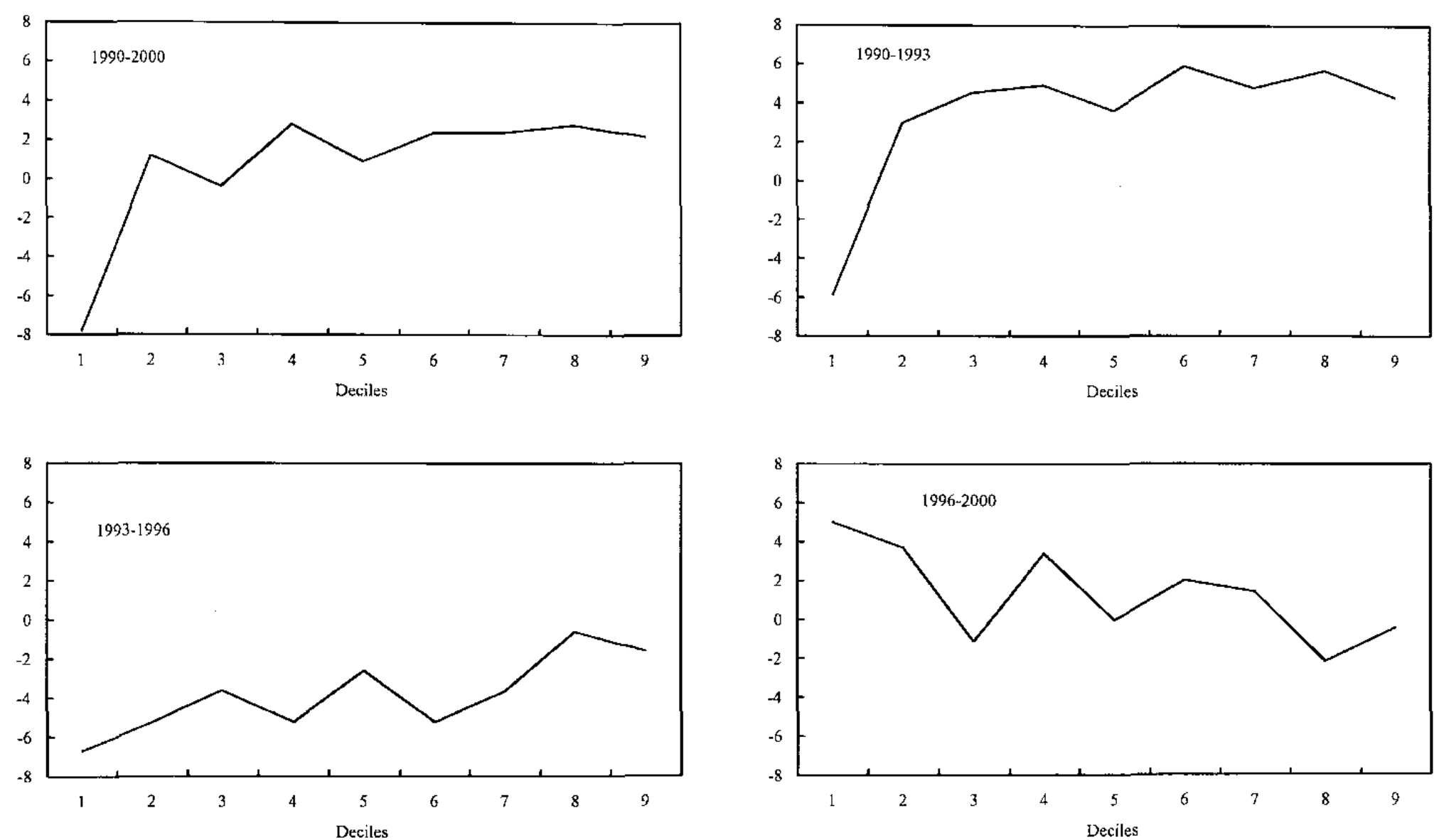

Sources: INSEE, Enquête Emploi; and authors' calculations. 
Figure 3. Real Hourly Wages by Deciles (Percent change)
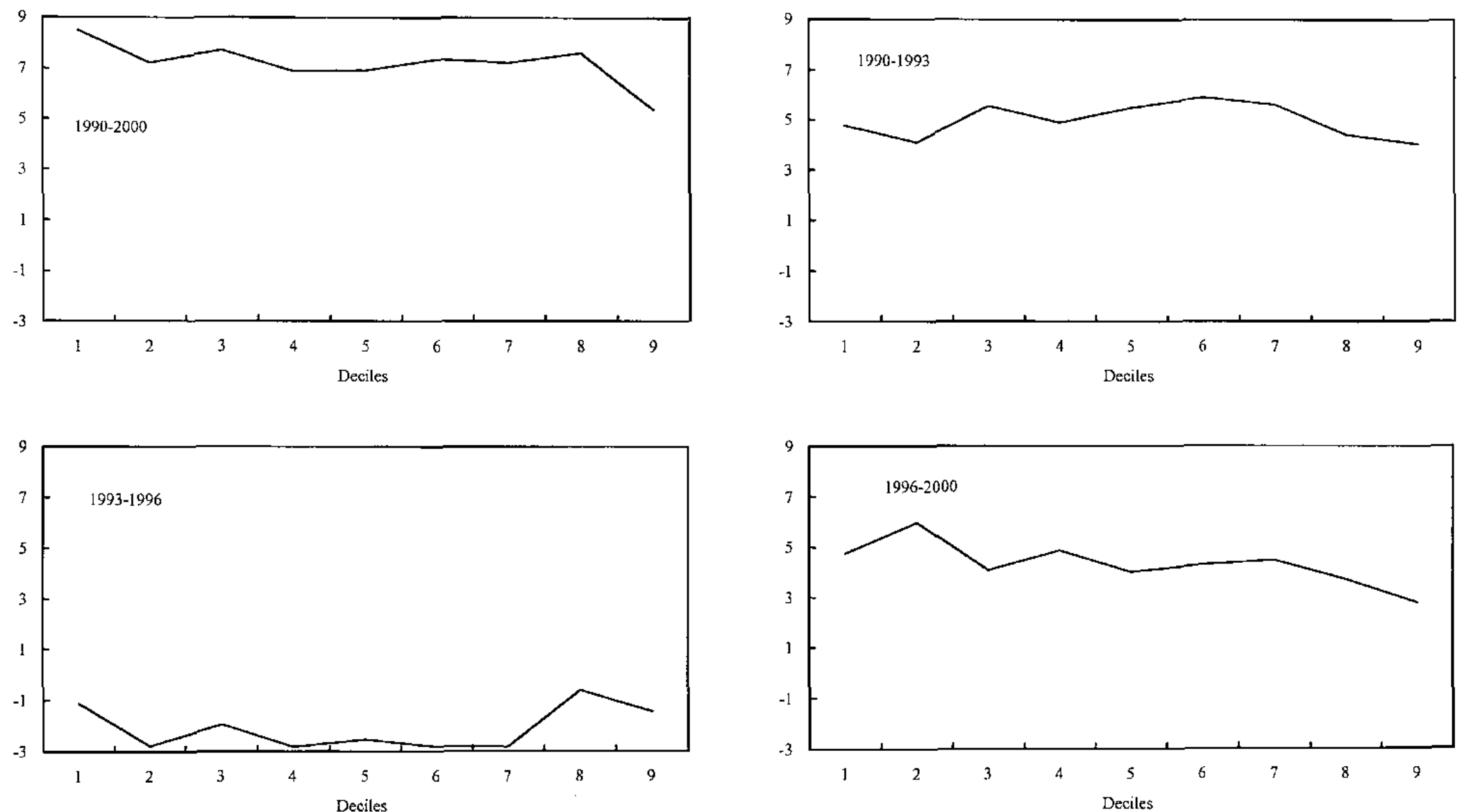

Sources: INSEE, Enquête Emploi; and authors' calculations. 
Figure 4. Employment Growth by Wage Deciles

(Percent change)
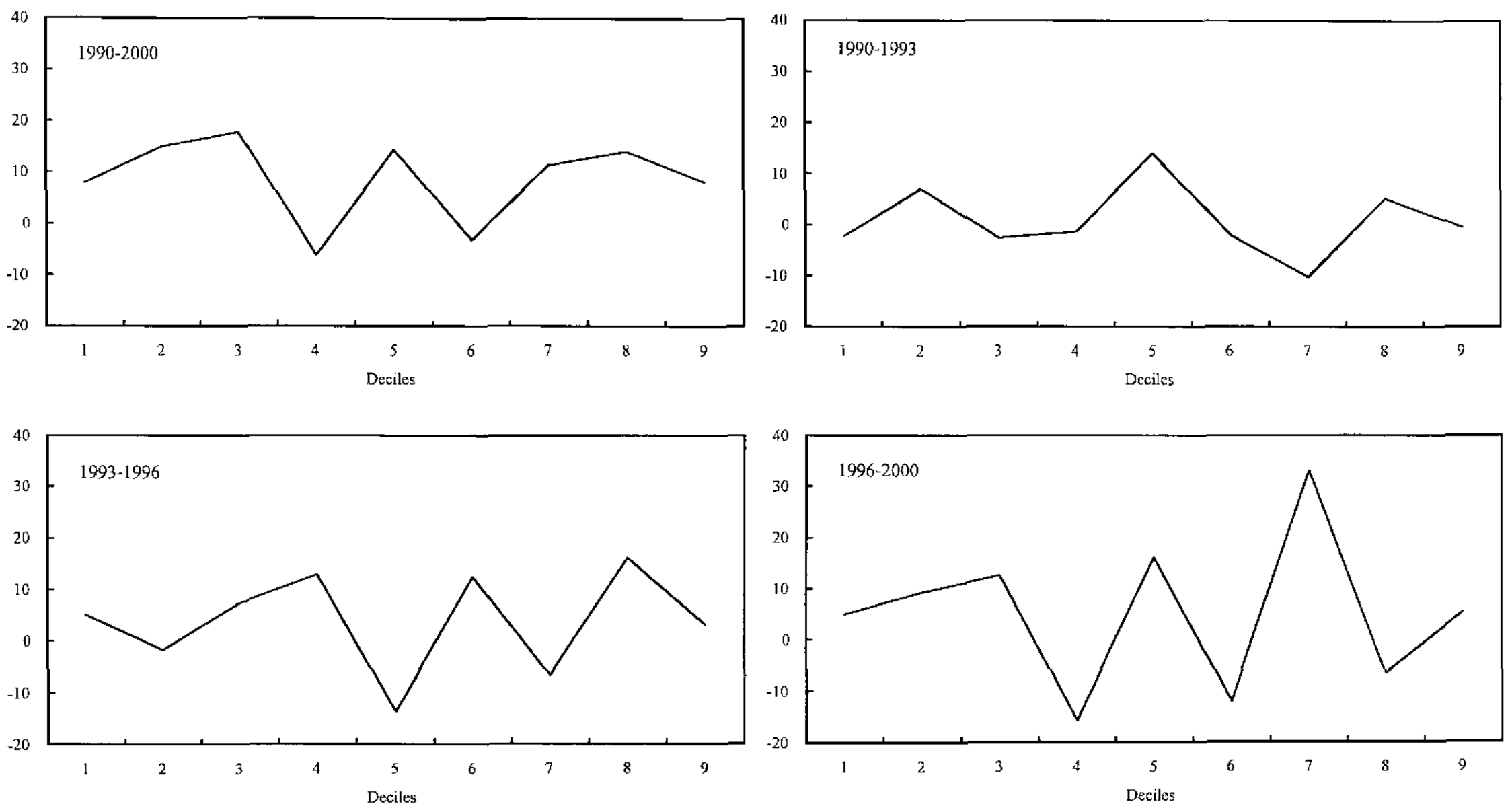

Sources: INSEE, Enquête Emploi; and authors' calculations. 


\section{Estimation}

With a view to identifying the presence of wage moderation in France in the late 1990s, we estimate a wage equation corresponding to equation (9) derived in Section II, using individual level data from the Enquête Emploi (see Appendix I for description of data). The following loglinear version is considered initially:

$$
\ln w_{i r t}=a+X_{i t}^{\prime} b+g \ln u_{r t}+d_{t}+d_{r}+e_{i r t},
$$

where $\ln$ refers to natural $\log , w_{i r}$ is the hourly wage rate of individual $i$ living in region $r$ in year $t, X_{i t}$ is a vector of individual observable characteristics, $u_{r t}$ is the unemployment rate in region $r$ at year $t, d_{t}$ and $d_{r}$ are, respectively, temporal and regional dummies, and $e_{i r t}$ is an i.i.d. error term.

Equation (10) has been used by Blanchflower and Oswald (1994) to show that, when estimating the relationship between regional unemployment and annual labor earnings, termed as the "wage curve," the elasticity of annual labor earnings with respect to regional unemployment rate is about -0.1 for virtually all the countries analyzed. ${ }^{12}$ Gianella (2000) provided the first evidence of a "wage curve" for France using a matched employer-employec pancl data in the private sector from the Déclarations Annuelles des Salariés (DAS) and Echantillon Démographique Permanent (EDP) for the period from 1984 to 1995, and 1990 excluded. His estimates vary between -0.05 and -0.1 for males. Compared to the present paper, he used a different database, time period (including a missing year in the middle of the sample), and methodology.

In estimating the relationship between unemployment and wages from survey data, it is necessary to guard against possible inefficient estimation that would result from covariance among individuals which is not entirely attributable to either their measured characteristics or the local unemployment rate (Moulton, 1986, 1990). To address this concern, the two-step estimation approach proposed by Card (1995) is used. In a first step, the following equation is estimated:

$$
\ln w_{i r t}=a+X_{i t}^{\prime} b+\sum_{r, t} \omega_{n t} \cdot 1_{\text {Re gion } r} \cdot 1_{\text {Time }=t}+e_{i r t} .
$$

This equation excludes the local unemployment rate, but includes interactive region and time dummies, whose coefficients can be interpreted as the average regional wage at time $t$ once individual characteristics are controlled for. In a second step, the adjusted wage variable - the estimated coefficients of the interactive region and time dummies-is regressed on time and region effects as well as on the regional unemployment rate as shown in equation (12):

${ }^{12}$ These countries were Australia, Austria, Canada, Germany, Ireland, Italy, Korea, the Netherlands, Norway, Switzerland, the United Kingdom and the United States. France was not part of their analysis. 


$$
\omega_{n t}=c+g \ln u_{r t}+d_{i}+d_{r}+e_{r t}
$$

To address possible simultaneity bias in equation (12) the lagged unemployment rate is used as instrument. $^{13}$

Several variations of equation (12) may prove to be important. First, the relationship between unemployment and wages may not be linear. In this case, higher order polynomials of the local unemployment rate can be used in the estimation of (12). Gianella (2000) found some evidence of a convex relationship between wages and unemployment in France. Second, since wages may not adjust immediately to variations in unemployment, lagged wages should be included, which is a common practice in the literature on the Phillips curve. ${ }^{14}$ Third, the elasticity of wages to unemployment may depend on the relevant group of individuals under consideration. Blanchflower and Oswald (1994) and Gianella (2000) showed that this is the case. For instance, the sensitivity of wages to unemployment is a bit larger for men than for women. It may also vary by workers' skill type. However, since the focus here is on average elasticities and individual characteristics are taken into consideration at least in the intercept of equation (10), this issue is not pursued further.

Finally, equation (12) assumes that the elasticity of wages with respect to the unemployment rate is unchanged across time. However, the model developed in Section II shows that technological and preference shocks affect not only the intercept of the wage curve but also its steepness. However, the lack of cross-sectional variation in the data prevents sufficiently precise yearly estimates of this elasticity to test for its time variance while at the same time including shifts in the intercept $c$-represented by $d_{t}$. An alternative solution would be to use equation (10) to perform such a test, but this procedure would suffer from the estimation problems mentioned earlier in this section. So, throughout the empirical exercise reported below, the elasticity of wages with respect to changes in the unemployment rate is held constant and the effect of variations in the markup of wages over workers' alternative income ( $m$ in equation (9)) on the estimated wage curve is assumed to be captured by time dummies. The assumption of constant elasticity of wages with respect to unemployment is necessary for the identification of "wage moderation" associated with an increase in unions" preference for employment or weakening of their bargaining power.

${ }^{13}$ The bias results from the possibility that higher wages cause lower labor demand and thus a higher rate of unemployment.

${ }^{14}$ See Bell (1996) and Blanchard and Katz (1997). 


\section{RESULTS}

In the first step of estimation, the nominal log hourly wage is regressed on demographic characteristics, dummies for full-time employment status, educational groups and their interactions with age groups, industries, occupation types, and interactions for region and year. All regressors but the interaction term for region and year are included primarily to control for the changing composition of the labor force over time as well as for individual-specific alternative income and tax liabilities if unemployed. The interactive time and regional dummies are deemed to capture aggregate price variations as well as technological progress (both important determinants of workers' income when unemployed) beside all other time/regional specific effects, including regional unemployment rates. The coefficients of these dummy variables can be interpreted as the hourly nominal wage for region $r$ at time $t$ once individual characteristics and idiosyncratic errors at the individual level are taken into account.

The estimated coefficients from the first step regression are presented in Table 8 in Appendix II. The signs of the structural coefficients of the preference shifters display the usual direction of impact of the individual characteristics such as age, gender, number of children, marital status, and employment status. ${ }^{15}$ Having controlled for the individual specific variations with the right signs of the estimated coefficients, we turn to the estimates obtained from the second step regression.

The results of the second step regression presented in Table 2 are more important for the present purpose. In this step, the coefficients of the time/region interactive dummies estimated from the first step are regressed on the log of regional unemployment rate and dummies for region and year. The instrumental variable (I.V.) estimate of the elasticity of the hourly wage with respect to the unemployment rate is -0.1 , the same value Blanchflower and Oswald (1994) found for several other countries using a different methodology. The smaller estimate (in absolute value) obtained by the OLS procedure is consistent with some simultaneity bias coming from a relationship between wages and unemployment driven by labor demand. The I.V. estimate indicates that wages are negatively correlated with local unemployment rates, controlling for individual demographic and labor market characteristics. It also shows that a doubling of the unemployment rate would be associated with a drop in hourly wages by 10 percent. Different

${ }^{15}$ It is found that female workers receive lower pay compared to male workers; wage increases with age but at a decreasing rate as indicated by the negative coefficient of the quadratic term of age; the number of children has a negative effect on hourly wage; married individuals are paid more than single, divorced, or widowed individuals; the hourly wage rate is higher for full-time workers than part-time workers; and wages increase with educational attainment. However, for many different specifications, the returns of having a technical diploma, which could take up to 12 years of education, were smaller than the returns of having the equivalent of a junior-high school diploma. This is a somewhat surprising result. The coefficients for type of activity and detailed occupation categories are also shown. 
specifications to capture a possible nonlinear relationship between wages and unemployment have been tried. Two of these specifications are reported in the last two columns of Table 2 . Higherorder terms are found statistically insignificant and their inclusion in the estimation procedure generates large standard errors for the coefficient of the linear term. These results are in contrast with Blanchflower and Oswald (1994) and Gianella (2000) who found a convex relationship between wages and unemployment.

All the regressions were replicated using annual earnings data-a less theoretically desirable variable but nonetheless another measure of labor income-to check for the robustness of the results to the definition of labor income. Estimates of the second-step regression using annual earnings are shown in Table 3 . These results also allow a better comparison with results in Blanchflower and Oswald (as well as the results in Gianella), which were obtained by using annual earnings. The estimated coefficients for the unemployment rate are remarkably similar to the ones shown in Table 2.

Table 2. Parameter Estimates from the Hourly Wage Regression

\begin{tabular}{|l|c|c|c|c|}
\hline \multicolumn{1}{|c|}{ Second Step } \\
\hline & \multicolumn{4}{|c|}{ Nominal log hourly wage adjusted for individual } \\
& \multicolumn{4}{|c|}{ characteristics } \\
\hline & OLS & I.V. & I.V. & I.V. \\
\hline Independent variable ${ }^{2}:$ & $-0.0298^{*}$ & $-0.0989 * *$ & -0.0428 & -0.0696 \\
Log regional unemployment & $(0.0141)$ & $(0.0295)$ & $(0.0943)$ & $(0.0561)$ \\
rate $\left(\mathrm{U}_{\mathrm{R}}\right)$ & & & 0.0117 & \\
$\mathrm{U}_{\mathrm{R}} * \mathrm{U}_{\mathrm{R}}$ & & & $(0.0190)$ & \\
$\mathrm{U}_{\mathrm{R}} * \mathrm{U}_{\mathrm{R}} * \mathrm{U}_{\mathrm{R}}$ & & & & $(0.0029)$ \\
\hline
\end{tabular}

Sources: INSEE, Enquête Emploi; and authors' calculations.

${ }^{1}$ Standard errors are in parentheses. ** and ${ }^{*}$ stand for 1 percent and 5 percent level of significance, respectively.

${ }^{2}$ Other independent variables included are time dummies and regional dummies. Lagged unemployment rate was used as instrument for the contemporaneous rate in the I.V. estimation. The square and the cube of lagged unemployment rate were used as instruments in the specifications with higher-order terms for the contemporaneous unemployment rate. 
Table 3. Parameter Estimates from the Annual Earnings Regression

\begin{tabular}{|c|c|c|}
\hline \multicolumn{3}{|c|}{ Second Step ${ }^{I}$} \\
\hline \multirow[t]{2}{*}{ Dependent Variable: } & \multicolumn{2}{|c|}{$\begin{array}{c}\text { Nominal Log Annual Earnings } \\
\text { Adjusted for Individual } \\
\text { Characteristics }\end{array}$} \\
\hline & OLS & I.V. \\
\hline $\begin{array}{l}\text { Independent variable }{ }^{2} \text { : } \\
\text { Log regional unemployment rate }\left(U_{R}\right)\end{array}$ & $\begin{array}{l}-0.0356^{* *} \\
(0.0132)\end{array}$ & $\begin{array}{c}-0.0993 * * \\
(0.0296)\end{array}$ \\
\hline
\end{tabular}

Sources: INSEE, Enquête Emploi; and authors' calculations.

${ }^{1}$ Standard errors are in parentheses. ${ }^{* *}$ and $*$ stand for l percent and 5 percent level of significance, respectively.

${ }^{2}$ Other independent variables included are time dummies and regional dummies. Lagged unemployment rate was used as instrument for the contemporaneous rate in the I.V. estimation.

Estimates for the alternative specification including lagged wages are presented in Table 4 . When using a one-period lag of the estimated coefficient for the region $\times$ year dummies, 1990 is dropped from the estimation process. The first set of I.V. results uses lagged unemployment as an instrument for the unemployment rate but not lagged wages. The coefficients are precisely estimated. The second set of estimates includes wages lagged twice as an instrument for wages lagged once to solve for the possibility that the fixed-effects estimates are biased due to the introduction of a lagged dependent variable and the small time dimension of the panel data. ${ }^{16}$ The point estimates are similar to the ones obtained with the first set of instruments but are not precisely measured. These results suggest that lagged wages might belong to the wage curve specification, but the low precision of the estimates leads to the acceptance of the static model as a better description of labor market functioning in France. In any case, if the estimated coefficients in the dynamic specification are taken at their face value, the implied long-run elasticity will be only just above -0.1 . The use of log annual earnings instead of log hourly wages in the dynamic specification does not change the results significantly. ${ }^{17}$

${ }^{16}$ Nickell (1981) and Anderson and Hsiao (1982) have shown that the bias declines as the time dimension increases, approaching zero as $T$ approaches infinity.

${ }^{17}$ Some papers use the existence of a possible dynamic specification for the wage curve as a test for the existence of a Phillips curve. While Blanchflower and Oswald (1994) and Gianella (2000) have not found any evidence for the importance of lagged wages in estimates of the wage curve, Blanchard and Katz (1997) and Bell (1996) suggest that this term may be important. The results shown here should be considered inconclusive. 
Table 4. Estimates of the Dynamic Specification

\begin{tabular}{|c|c|c|c|}
\hline \multicolumn{4}{|c|}{ Dependent variable: log hourly wage } \\
\hline Coefficients & OLS & I.V. . & I.V.2 \\
\hline Lagged wage & $0.35^{* * *}$ & $0.33^{* * *}$ & 0.47 \\
& $(0.0685)$ & $(0.0632)$ & $(0.2958)$ \\
\hline Unemployment rate & $-0.02^{*}$ & $-0.08^{* * *}$ & -0.08 \\
& $(0.0108)$ & $(0.0271)$ & $(0.0906)$ \\
\hline \multicolumn{3}{|c|}{ Dependent variable: $\log$ annual earnings } \\
\hline Coefficients & OLS & I.V.1 & I.V. 2 \\
\hline Lagged wage & $0.34^{* * *}$ & $0.31^{* * *}$ & 0.38 \\
& $(0.0706)$ & $(0.0676)$ & $(0.3297)$ \\
\hline Unemployment rate & -0.02 & $-0.07^{* *}$ & -0.09 \\
& $(0.0111)$ & $(0.0280)$ & $(0.1094)$ \\
\hline
\end{tabular}

Sources: INSEE, Enquête Emploi; and authors' calculations.

Notes:

1. The first set of I.V. estimates (I.V. 1) uses lagged unemployment as an instrument for contemporaneous unemployment. The second set of instruments (I.V. 2) includes twice-lagged wage as an instrument for lagged wages in the vector of instruments used in I.V. 1. Other independent variables included in the regression are time dummies and regional dummies.

2. Standard errors are in parentheses. ${ }^{* *},{ }^{* *}$, and ${ }^{*}$ stand for significance at 1 percent, 5 percent, and 10 percent, respectively.

\section{Empirical EVidence of Wage moderation in France}

Using the results of the previous section, and taking into account changes in the tax wedge and unemployment income, there is strong evidence of wage moderation in France during the 1990s (Table 5). Shifts in the relationship between unemployment and wages are captured by the coefficients of the time dummies in equation(12). These shifts can be caused not only by changes in the parameter $m$ in equation (9) but also by changes in aggregate unemployment income and in tax wedges, since they were not directly controlled for during the estimation of equation (12). To account for these latter effects, the estimated intercept for each year was divided by the CPI and by an index measuring technological progress, and corrected for the path of aggregate income tax rates. The technological progress index was measured by accumulating changes in total factor productivity scaled by the labor share.

Pure composition effects, changes in the CPI, and technological growth are assumed to capture, among other things, changes in income when unemployed. The allowance for individual level variations in the measure of alternative income through the pure composition effects presents a substantial improvement in this study over the conventional practice of using aggregate measures of alternative income. As for example, Abowd and Lemieux (1993) measured alternative income at the firm level by using average wage of the industrial composite in Canada. The consideration that this aggregate measure may be inadequate to capture the variations in market alternatives leads them to use the provincial wage rates and the provincial unemployment rates as well to measure alternative wage. 
As shown in Table 5, nominal hourly wages increased about 20 percent between 1991 and $2000{ }^{18}$ The time-specific intercepts of equation (12)-which equals the intercept in 1991 plus the coefficient of each respective time dummy - can be interpreted as the nominal hourly wages once composition and unemployment effects are taken into account. Thus adjusted wages increased only 2 percentage points less than the unadjusted series. But after taking inflation and technology into account, wages fell by more than 10 percent. Put differently, real wages adjusted for composition and unemployment grew 10 percent less than productivity. Finally, adjusting further for income taxes, wages fell by 16 percent; or, after-tax wages (adjusted for all measured factors) fell by 16 percent. In summary, real hourly wages fell behind productivity, and wage demands were moderate despite an increase in income tax rates (which, ceteris paribus, should have raised them by about 6 percentage points).

Such a negative trend in the adjusted time-specific intercept of (12) implies that the wage curve shifted downward; or that, for a given state of labor demand, unemployment was smaller at each wage level. Figure 5 shows the actual shifts in the wage curve in France during the 1990s, defined as the relationship between one minus the unemployment rate and real hourly wages adjusted for productivity, taxes, and changes in the composition of employment; a standard way to present what is sometimes referred to as a "labor supply-like" curve. It is interesting to note that the shift was larger during the latest expansion when the labor intensity of growth seemed to have increased relative to historic experience.

Table 5. France: Hourly Wage Growth in the Nonfarm Business Sector (Percent change)

\begin{tabular}{|ccccc|}
\hline Period & Hourly wage & $\begin{array}{c}\text { (a) Adjusted for } \\
\text { composition changes } \\
\text { and the effect of the } \\
\text { unemployment rate }\end{array}$ & $\begin{array}{c}\text { (b) Adjusted for } \\
\text { inflation and } \\
\text { productivity }\end{array}$ & $\begin{array}{c}\text { (c) Adjusted for } \\
\text { changes in average } \\
\text { income taxes }\end{array}$ \\
\hline $1991-93$ & $(1)$ & $(2)$ & $(3)$ & $(4)$ \\
$1993-96$ & 9.15 & 8.06 & 3.19 & 2.65 \\
$1996-2000$ & 1.49 & 2.56 & -6.12 & -6.81 \\
$1991-2000$ & 8.51 & 6.70 & -7.58 & -12.68 \\
\hline
\end{tabular}

Sources: Hourly wages from INSEE, Enquête Emploi; and authors' estimates of equation (12). Inflation is measured by changes in CPI, INSEE. Technological progress is TFP growth adjusted for the share of labor income, OECD and INSEE. Average incomc taxes from the tax and benefits database, OECD. 'Column (2) refers to the time specific intercept implicit in the estimate of equation (12).

${ }^{18}$ Because lagged unemployment rates are used as instruments for the estimation of equation (12), the year 1990 is dropped from the sample. 
Figure 5. Shifts in the Wage Curve

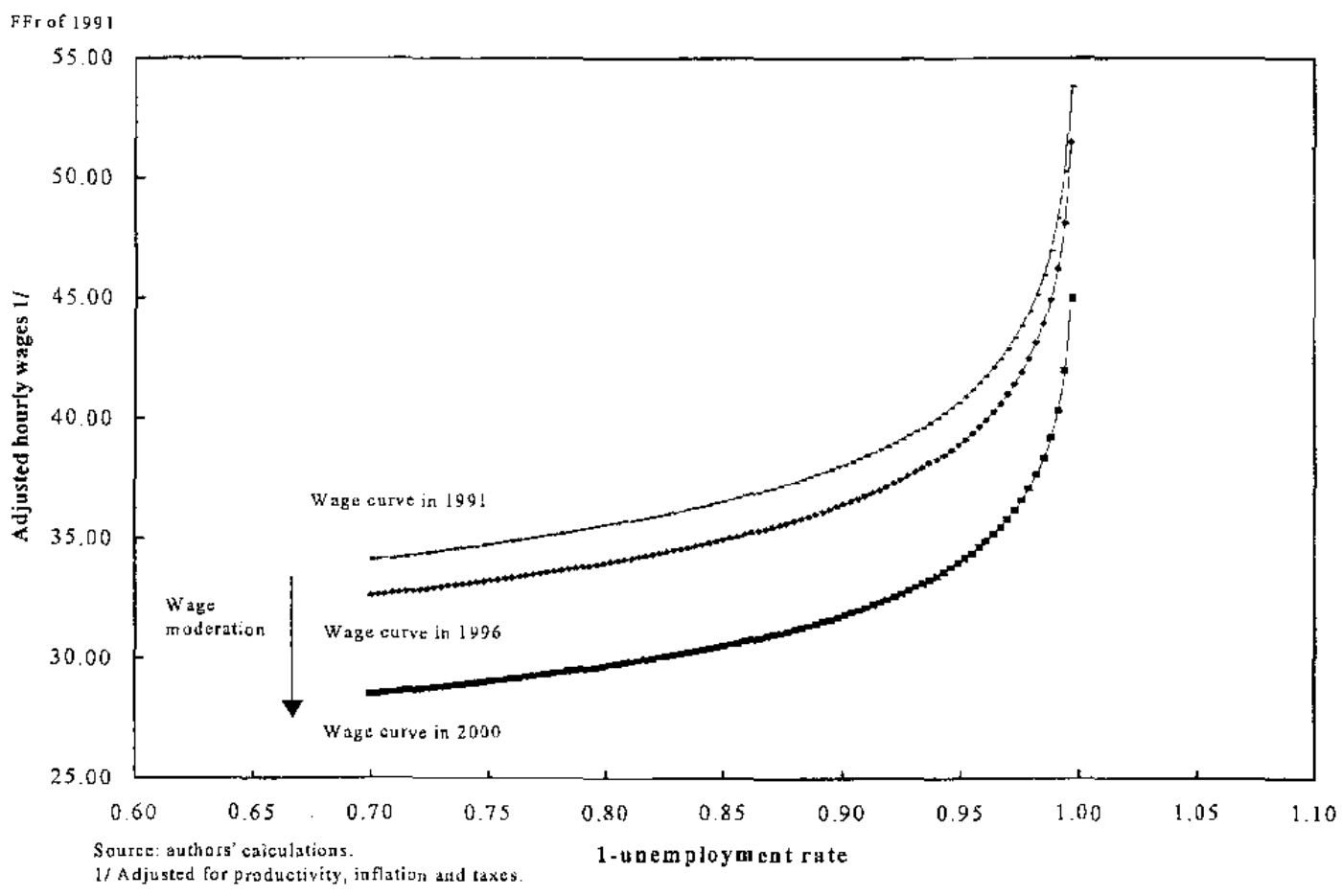

As mentioned in Section II, in order to isolate the effect of wage moderation interpreted as a change in unions' preferences toward.employment or a decline in their bargaining power, it is necessary to control for the effects of the income a worker would reccive if unemployed, the tax wedge between labor income and unemployment income, technological change, and elasticity of product market demand. One may argue that not all of these factors have been adequately controlled for in the above empirical estimation. So we need to diagnose the potential biases caused by the omission of these unaccounted for factors in the above quantification.

First, we consider technological changes, which in equilibrium are equivalent to changes in the labor share (1- $\alpha$ in equation (9)). An increase in the labor intensity in production could cause wage demand to flag due to diminished marginal productivity of labor. But the share of labor income in GDP throughout the 1990s was broadly unchanged. The constant trend in the labor share in the business sector in France in most parts of the 1990s is evident in Figure 6.

Second, it is possible that inflation and productivity growth are imperfect proxies for the income received when unemployed. For instance, they do not capture changes in labor market institutions such as unemployment insurance schemes or changes in marginal tax rates. It is well recognized that benefits as well as income taxes in France interact so as to provide disincentive to work. A number of recent studies show empirical evidence in support of this phenomenon (see Laroque and Salanié, 1999, 2000; Bourguignon and Bureau, 1999; Afsa and Guillemot, 1999). 
Figure 6. Labor Share and Replacement Rates

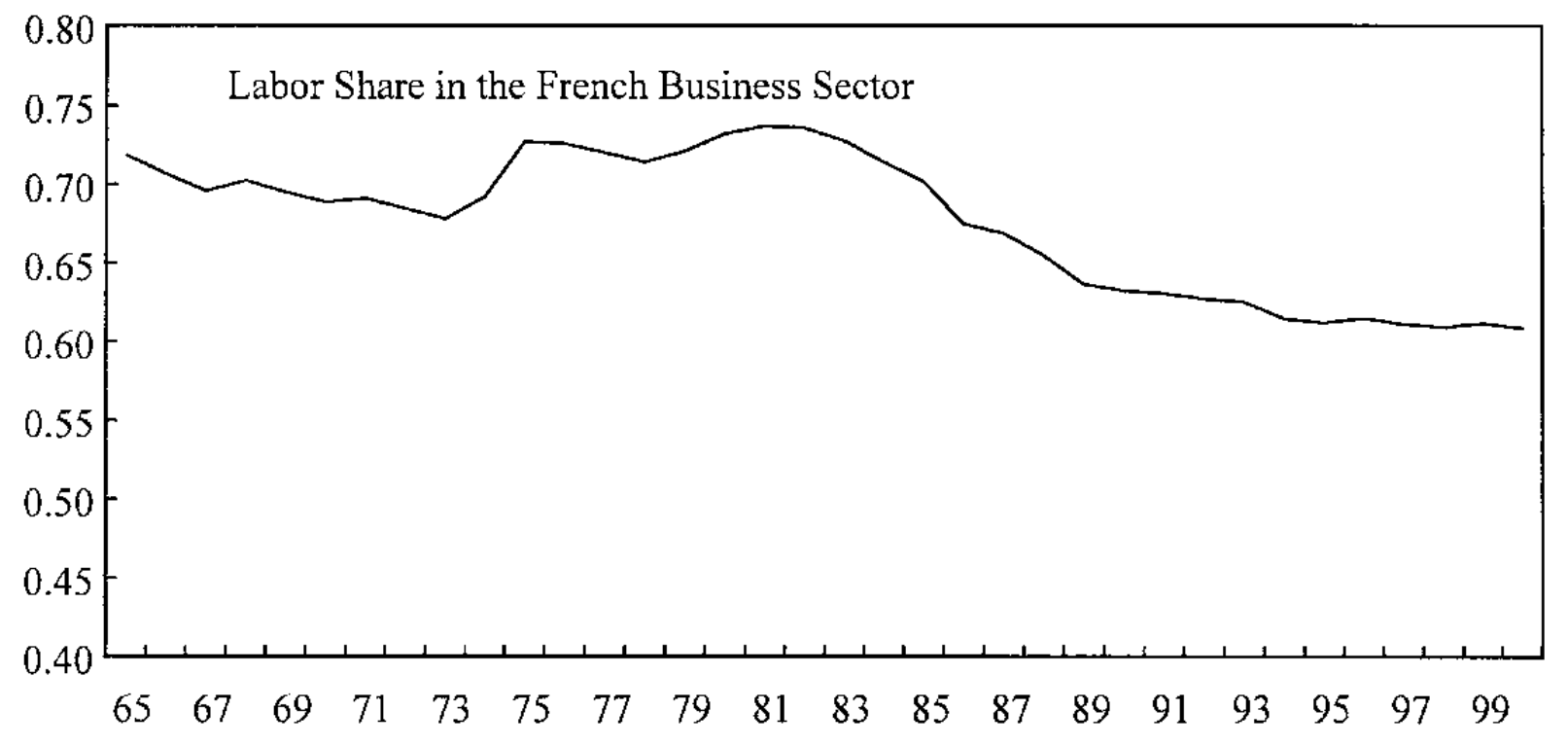

Sources: OECD and authors' calculations.

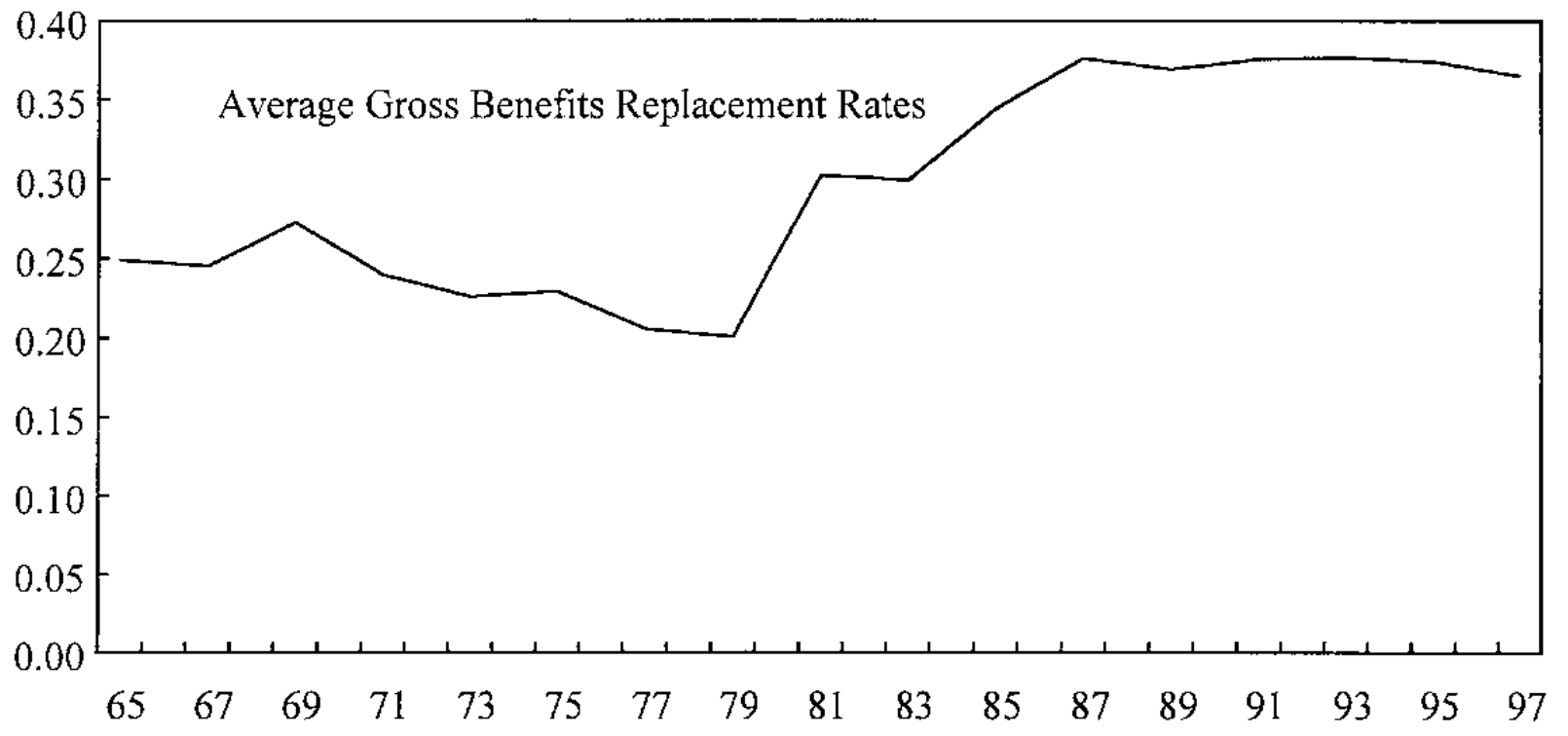

Sources: OECD tax and benefits database and authors' calculations. 
Given the narrow base of the income tax, high marginal rates at the low end of the income distribution result essentially from the withdrawal of benefits. According to Laroque and Salanié (1999), 57 percent of nonemployment, termed as "voluntary unemployment," results from taxbenefit disincentives to work. However, OECD data for gross benefit replacement rates do not show significant changes in the ratio of benefits to labor income in the 1990s at least until 1997, the last available data point (see lower panel of Figure 6). In view of this scenario, it is plausible to assume that our empirical model provides a reasonable approximation to the trend in income when unemployed.

Third, the observed shift in the wage curve could have been caused by the process of globalization of production, which might have increased product market competition and the elasticity of product demand. Such a development would cause a downward shift in the wage curve because unions would take into account the adverse effects of high wage demands on production costs and, ultimately, on the amount produced and sold. It is hard to disentangle this effect from pure changes in unions' preferences and many analysts would in any case interpret this product market effect as a reduction of unions' bargaining power.

Fourth, part of the observed wage moderation since 1996 might have been caused by negotiations within firms that adopted the 35-hour workweek following the introduction of the 1996, 1998, and 2000 laws. Passeron (2000) shows that firms that adopted the 35-hour workweek following the 1996 and 1998 laws posted larger employment growth than other similar firms. This may be an outcome of increased workers' preference for employment associated with a mandatory cutback in the number of hours worked.

\section{Conclusion}

During the 1990s, the growth rate of real hourly wages in France fell below the trend growth rate of total factor productivity. In a right-to-manage model, in which firms and labor unions bargain over wages but firms determine employment levels- - a realistic approximation of French labor market institutions-wage moderation is defined here as an increase in preferences of workers toward employment or a reduction in union bargaining power. These changes would cause a downward shift in the relationship between wages and unemployment and an increase in employment given the state of labor demand. Microeconometric estimates using annual household level survey data-which allow the level of wages to be related to individual characteristics and local labor market conditions - provide evidence of such an outward shift in the relationship between wages and unemployment that is independent of changes in labor demand, taxes, and unemployment income. The exercise performed here does not pin down the possible sources for the changes in unions' preference or overall bargaining power. Structural changes in labor market institutions may be behind the shift in the wage curve, although it is hard to measure institutional changes or their direct relationship to unions' behavior. 


\section{DATA DESCRIPTION}

The Enquête Emploi (EE) is an annual employment survey conducted by the Institut National de la Statistique et des Études Économiques (INSEE) in March of every year (with the exception of the year 1999 when the survey was undertaken in January). It collects information of individuals at the household level. The sample period used here runs from 1990 through 2000. Information for years prior to 1990 were not used due to the reporting of the wage variable in brackets as opposed to discrete numbers. From this dataset individual specific information is available on demographic characteristics (e.g., age, sex, marital status, number of children in the household), level of education, and labor market characteristics (e.g., labor force participation status, employment status, net monthly salary in the main job, number of hours worked in the main job during the week before the interview, industry, and type of occupation) and the region of residence.

The dataset has a large sample of around 1.6 million observations for the population aged 15 years or more (about 146,000 observations, on average, for every year, see Table 6). One-third of the sample from the previous year is replaced with new respondents every year. Nevertheless, individuals were treated as cross-sectional observations. Individuals between 15 and 64 years of age who reported positive net monthly salary in a regular job have been selected for the regression analysis. The selected sample excludes extreme observations, public sector employees, self-employed, apprentices, retired, inactive and those employed in the agricultural sector and military service. ${ }^{19}$ The final sample used in the estimation of equations (11) and (12) had 235,545 pooled cross-sectional observations for France over the period from 1990 through 2000 . The paper departs from the convention of selecting prime-age, male, full-time workers with a view to controlling for the changing composition of the labor force by age, sex, employment status, and other demographic and sectoral classification of occupation in the wage regression.

The wage variable used here is the reported monthly salary net of social security contributions in the principal job (thus, it is the pre-income tax wage). Whenever the analysis refers to the annual salary, the monthly variable is multiplied by 12 . The annual labor earning variable is obtained by adding nonwage annual benefits to annual net salary. The hourly wage variable, on the other hand, has been calculated by dividing the net monthly salary by 4.33 and the number of hours worked in the main job in the week prior to the interview. Overtime hours are recorded in the weekly hours variable only when the individual worked more during the reference week than during a normal week. If the individual systematically works more than the legal working time (supplementary hours), these extra hours are not recorded separately. There is a potential measurement error in the weekly hours variable for those respondents who worked less

${ }^{19}$ Extreme observations are characterized by a net salary that satisfies:

$\mid$ Individual salary - median salary $\mid>3 \times\left(75^{\text {th }}\right.$ percentile $-25^{\text {th }}$ percentile $)$. 
than usual hours in the reference week due to illness, strike, weather condition, going to retirement or unemployment, or other plausible reasons for temporary drops in labor supply.

Table 6. Size of Full and Selected Sample

\begin{tabular}{|c|c|c|}
\hline Year & $\begin{array}{c}\text { Full Sample } \\
\text { (15 years and older) }\end{array}$ & Selected Sample \\
\hline 1990 & 136,281 & 24,209 \\
\hline 1991 & 137,298 & 22,833 \\
\hline 1992 & 141,053 & 24,001 \\
\hline 1993 & 146,803 & 26,005 \\
\hline 1994 & 151,590 & 27,111 \\
\hline 1995 & 151,146 & 26,845 \\
\hline 1996 & 150,365 & 26,799 \\
\hline 1997 & 148,891 & 25,901 \\
\hline 1998 & 149,132 & 25,700 \\
\hline 1999 & 148,867 & 25,055 \\
\hline 2000 & 148,775 & 24,892 \\
\hline
\end{tabular}

Sources: INSEE, Enquête Emploi.

No information is available on individuals' tax liability or income when unemployed, but the effects are likely to be partly picked up by the dummies representing individual characteristics. To measure changes in the tax wedge, data on average income tax rates for different types of families from the OECD tax and benefits database were used. Thus, it is implicitly assumed that changes in average income tax rates did not affect after-tax unemployment income.

The regional unemployment rate, included in the list of explanatory variables in the second-step equation (12), shows wide disparity across regions over time ranging from a low of 4.84 percent in 1990 to 19.6 percent in 1996 (Table 7). This wide regional variation improves the identification of a relationship between wages and the unemployment rate that would have otherwise been obtained by using only aggregate time series data. 
Table 7. Weighted Regional and National Unemployment Rate (In percent)

\begin{tabular}{crrrrrrrrrrrr}
\hline Region & 1990 & 1991 & 1992 & 1993 & 1994 & 1995 & 1996 & 1997 & 1998 & 1999 & 2000 \\
\hline & & & & & & & & & & & & \\
1 & 7.08 & 6.84 & 7.91 & 9.75 & 11.16 & 10.24 & 10.92 & 11.02 & 10.69 & 10.37 & 8.57 \\
2 & 11.42 & 9.78 & 11.33 & 12.87 & 12.74 & 12.41 & 12.43 & 12.81 & 12.98 & 13.03 & 11.06 \\
3 & 11.70 & 9.57 & 10.65 & 12.13 & 13.25 & 12.60 & 10.84 & 14.13 & 12.58 & 13.21 & 11.46 \\
4 & 9.71 & 10.44 & 10.82 & 11.30 & 13.08 & 12.85 & 12.70 & 12.71 & 14.08 & 13.92 & 10.78 \\
5 & 8.89 & 8.08 & 8.74 & 9.73 & 11.14 & 9.60 & 10.85 & 11.46 & 10.32 & 10.64 & 8.08 \\
6 & 10.55 & 8.98 & 8.49 & 8.97 & 11.00 & 10.19 & 10.78 & 11.70 & 10.48 & 9.62 & 8.26 \\
7 & 7.86 & 9.36 & 11.10 & 10.00 & 11.55 & 10.45 & 10.62 & 11.72 & 9.59 & 10.25 & 9.25 \\
8 & 13.56 & 14.18 & 15.40 & 16.10 & 17.43 & 17.70 & 18.57 & 18.73 & 18.55 & 17.83 & 16.66 \\
9 & 7.98 & 8.44 & 10.32 & 11.24 & 12.19 & 11.46 & 11.58 & 11.76 & 10.95 & 11.05 & 9.68 \\
10 & 4.84 & 4.86 & 5.69 & 8.00 & 8.82 & 7.24 & 7.57 & 7.98 & 7.84 & 7.45 & 6.35 \\
11 & 7.62 & 7.32 & 9.27 & 9.55 & 9.58 & 9.18 & 9.31 & 9.34 & 9.96 & 9.30 & 7.86 \\
12 & 8.84 & 8.83 & 10.85 & 9.87 & 11.77 & 10.03 & 11.93 & 11.30 & 11.91 & 11.68 & 9.08 \\
13 & 8.46 & 9.15 & 8.86 & 9.90 & 9.51 & 9.63 & 9.67 & 10.09 & 9.17 & 9.02 & 7.21 \\
14 & 10.95 & 11.63 & 10.75 & 12.04 & 11.47 & 11.33 & 9.75 & 10.85 & 10.52 & 10.81 & 8.11 \\
15 & 10.54 & 10.83 & 11.04 & 10.92 & 13.25 & 11.83 & 12.54 & 12.06 & 10.53 & 11.81 & 11.01 \\
16 & 8.15 & 8.61 & 10.02 & 10.66 & 12.47 & 11.94 & 11.99 & 12.18 & 10.12 & 11.03 & 9.89 \\
17 & 10.68 & 9.42 & 8.67 & 8.03 & 10.01 & 8.68 & 9.62 & 9.55 & 8.45 & 9.32 & 7.77 \\
18 & 7.10 & 6.93 & 8.12 & 10.57 & 11.78 & 10.50 & 10.15 & 10.35 & 9.73 & 9.70 & 7.99 \\
19 & 8.41 & 8.68 & 10.61 & 10.07 & 11.19 & 10.46 & 10.84 & 10.30 & 9.69 & 10.08 & 9.89 \\
20 & 14.38 & 13.66 & 15.12 & 15.90 & 18.57 & 16.05 & 19.60 & 18.56 & 18.57 & 17.20 & 16.37 \\
21 & 12.37 & 12.02 & 13.19 & 14.65 & 15.28 & 16.23 & 16.92 & 17.21 & 17.24 & 17.20 & 14.38 \\
National & 9.24 & 9.11 & 10.12 & 11.21 & 12.47 & 11.67 & 12.18 & 12.38 & 11.90 & 11.82 & 10.09 \\
Min & 4.84 & 4.86 & 5.69 & 8.00 & 8.82 & 7.24 & 7.57 & 7.98 & 7.84 & 7.45 & 6.35 \\
Max & 14.38 & 14.18 & 15.40 & 16.10 & 18.57 & 17.70 & 19.60 & 18.73 & 18.57 & 17.83 & 16.66 \\
Std & 2.34 & 2.22 & 2.28 & 2.25 & 2.42 & 2.58 & 3.01 & 2.85 & 3.08 & 2.84 & 2.81 \\
\hline
\end{tabular}

Sources: INSEE, Enquête Emploi; and authors' calculations. 


\section{Detailed Regression Results}

Table 8. Results of the First-Step Regression

\begin{tabular}{|c|c|c|c|c|}
\hline \multirow[b]{3}{*}{ Independent variables } & \multicolumn{4}{|c|}{ Dependent variable } \\
\hline & \multicolumn{2}{|c|}{ Nominal log hourly wage } & \multicolumn{2}{|c|}{ Nominal log annual eamings } \\
\hline & Parameter & Standard & Parameter & Standard \\
\hline & estimate & crror & estimate & error \\
\hline Constant & 2.7694 & 0.0176 & 9.9114 & 0.0160 \\
\hline Female & -0.1147 & 0.0016 & -0.1510 & 0.0014 \\
\hline Age & 0.0555 & 0.0007 & 0.0593 & 0.0007 \\
\hline Age*Age & -0.0006 & 0.0000 & -0.0006 & 0.0000 \\
\hline Number of children & -0.0110 & 0.0005 & -0.0141 & 0.0005 \\
\hline Married & 0.0339 & 0.0014 & 0.0373 & 0.0013 \\
\hline Full-time status & 0.0177 & 0.0023 & 0.4770 & 0.0020 \\
\hline \multicolumn{5}{|l|}{ Education: } \\
\hline $\mathrm{JH}$ & 0.1824 & 0.0105 & 0.1641 & 0.0096 \\
\hline $\mathrm{TD}$ & 0.1035 & 0.0057 & 0.1029 & 0.0051 \\
\hline$\overline{\mathrm{BAC}}$ & 0.2016 & 0.0094 & 0.2152 & 0.0085 \\
\hline $\mathrm{BAC}+2$ & 0.2748 & 0.0159 & 0.2685 & 0.0143 \\
\hline $\mathrm{BAC}+4$ & 0.4276 & 0.0124 & 0.4499 & 0.0113 \\
\hline \multicolumn{5}{|c|}{ Interaction of age groups and education: } \\
\hline gl ${ }^{*}$ no-diploma & -0.0979 & 0.0058 & -0.0979 & 0.0052 \\
\hline $\mathrm{gI}{ }^{*} \mathrm{JH}$ & -0.2885 & 0.0122 & -0.2784 & 0.0110 \\
\hline $\mathrm{g} 1$ *TD & -0.0302 & 0.0063 & -0.0155 & 0.0057 \\
\hline $\mathrm{g}{ }^{*} \mathrm{BAC}$ & -0.1462 & 0.0103 & -0.1774 & 0.0094 \\
\hline $\mathrm{g} 1 * \mathrm{BAC}+2$ & -0.2188 & 0.0171 & -0.2268 & 0.0155 \\
\hline $\mathrm{g} 1 * \mathrm{BAC}+4$ & -0.3893 & 0.0194 & -0.4703 & 0.0178 \\
\hline g2*no-diploma & -0.0397 & 0.0044 & -0.0389 & 0.0040 \\
\hline $\mathrm{g} 2 * \mathrm{JH}$ & -0.1518 & 0.0106 & -0.1237 & 0.0097 \\
\hline $\mathrm{g} 2 * \mathrm{TD}$ & -0.0772 & 0.0056 & -0.0682 & 0.0050 \\
\hline $\mathrm{g} 2 * \mathrm{BAC}$ & -0.1284 & 0.0094 & -0.1311 & 0.0086 \\
\hline $\mathrm{g} 2 * \mathrm{BAC}+2$ & -0.1711 & 0.0159 & -0.1425 & 0.0144 \\
\hline $\mathrm{g} 2 * \mathrm{BAC}+4$ & -0.2571 & 0.0124 & -0.2462 & 0.0114 \\
\hline \multicolumn{5}{|l|}{ Economic sectors: } \\
\hline Utilities & 0.0986 & 0.0039 & 0.0637 & 0.0035 \\
\hline Construction & -0.0235 & 0.0021 & -0.0237 & 0.0019 \\
\hline Retail trade & -0.0723 & 0.0018 & -0.0623 & 0.0016 \\
\hline Transport & 0.0221 & 0.0024 & 0.0201 & 0.0022 \\
\hline Financial sector & 0.0675 & 0.0029 & 0.0641 & 0.0026 \\
\hline Real estate & -0.0919 & 0.0046 & -0.0884 & 0.0042 \\
\hline
\end{tabular}


Table 8. (continued)

\begin{tabular}{|c|c|c|c|c|}
\hline \multicolumn{5}{|l|}{ Occupation categories: } \\
\hline Craftsmen and owner of related small business & -0.2060 & 0.0178 & -0.0772 & 0.0163 \\
\hline Small business owner in trade and services & -0.1032 & 0.0181 & 0.0225 & 0.0166 \\
\hline Head of firms with 10 or more employecs & 0.3158 & 0.0188 & 0.5084 & 0.0172 \\
\hline Professionals & 0.1913 & 0.0485 & 0.1471 & 0.0436 \\
\hline Managers in the public sector & 0.2060 & 0.0159 & 0.1835 & 0.0143 \\
\hline Professors and scientists & 0.2959 & 0.0147 & 0.2171 & 0.0132 \\
\hline Managers in the private sector & 0.2625 & 0.0101 & 0.3444 & 0.0092 \\
\hline Engineers and technical experts & 0.2958 & 0.0101 & 0.3555 & 0.0092 \\
\hline Teachers and related occupations & 0.0869 & 0.0178 & 0.0311 & 0.0162 \\
\hline Workers in health and social services & -0.0491 & 0.0116 & -0.0883 & 0.0106 \\
\hline Clergymen & -1.1292 & 0.2792 & -1.0833 & 0.2665 \\
\hline Middlc-management in the public admin. & -0.0019 & 0.0098 & 0.0026 & 0.0090 \\
\hline Middle-management in the private sector & 0.0451 & 0.0126 & -0.0143 & 0.0115 \\
\hline Technicians & 0.0136 & 0.0099 & -0.0359 & 0.0090 \\
\hline Foremen & 0.0428 & 0.0100 & 0.0171 & 0.0091 \\
\hline Civil servants & -0.1703 & 0.0109 & -0.2356 & 0.0099 \\
\hline Police and armed forces officers & -0.1657 & 0.0140 & -0.2140 & 0.0128 \\
\hline Clerical workers in the private sector & -0.1058 & 0.0098 & -0.1480 & 0.0090 \\
\hline Sales workers & -0.2398 & 0.0099 & -0.2790 & 0.0091 \\
\hline Service workers to individuals or households & -0.4656 & 0.0119 & -0.4769 & 0.0109 \\
\hline Skilled blue-collars in industry & -0.1414 & 0.0098 & -0.2089 & 0.0089 \\
\hline Skilled manual workers & -0.1937 & 0.0099 & -0.2517 & 0.0090 \\
\hline Drivers & -0.2568 & 0.0101 & -0.2548 & 0.0092 \\
\hline Maintenance, transportation and storage workers & -0.1629 & 0.0101 & -0.2301 & 0.0093 \\
\hline Low-skill blue-coliars in industry & -0.2557 & 0.0098 & -0.3192 & 0.0090 \\
\hline Low-skill manual workers & -0.3671 & 0.0101 & -0.4773 & 0.0093 \\
\hline Number of observations & 235,562 & & 259,831 & \\
\hline Adjusted $\mathrm{R}^{2-}$ & 0.51 & & 0.66 & \\
\hline F-statistic & 875.2 & & 1733.1 & \\
\hline
\end{tabular}

Sources: INSEE, Enquête Emploi; and authors' estimation.

Notes:

Bolded coefficients are significant at 1 percent level;

Age group dummies: if $15<=\mathrm{agc}<25$ then $\mathrm{g} 1=1$, else $\mathrm{g} 1=0$; if $25<=\operatorname{agc}<55$ then $\mathrm{g} 2=1$, else $\mathrm{g} 2=0$; if 55 $<=$ agc then $\mathrm{g} 3=1$; else $\mathrm{g} 3=0$.

Educational categories: $\mathrm{JH}=$ Junior-high school diploma; $\mathrm{TD}=$ Technical diploma; $\mathrm{BAC}=$ Baccalaureat; $\mathrm{BAC}+2=$

$\mathrm{BAC}+2$ years of education; $\mathrm{BAC}+4=\mathrm{BAC}+$ minimum of 4 years of education.

Control group: Male, single, part-time, no-school diploma, interaction between g3 age group and education variables, industrial sector, and journalists, entertainers and artists. 


\section{REFERENCES}

Abowd, John, and T. Lemieux, 1993, "The Effects of Product Market Competition on Collective Bargaining Agreements: The Case of Foreign Competition in Canada," Quarterly Journal of Economics, 108(4): 983-1014, November.

Afsa, Cédric and Guillemot, Danièle, 1999, "Plus de la moitié des sorties du RMI se font grâce à l'emploi," INSEE Première, No. 632, February.

Anderson, T. W., and Cheng Hsiao, 1982, "Estimation of Dynamic Models with Error Components," Journal of the American Statistical Association, 76(375):589-606, September.

Bell, B., 1996, “Wage Curve or Phillips Curve?" unpublished, Oxford: Nuffield College.

Blanchard, Olivier, 1997, "The Medium Run," Brookings Papers on Economic Activity: 2, pp. 89-158.

- - 2000, "The Economics of Unemployment: Shocks, Institutions, and Interactions," Lionel Robbins Lecture, London School of Economics, October.

- and Larry Katz, 1997, "What We Know and Do Not Know About the Natural Rate of Unemployment," Journal of Economic Perspectives, 11(1):51-72.

Blanchflower, David G., and Oswald, Andrew J., 1994, The Wage Curve, Cambridge, Massachusetts: MIT Press.

- 1995, "An Introduction to the Wage Curve," Journal of Economic Perspectives, 9(3):153-67.

Bourguignon, François, and Burcau, Dominique, 1999, L'architecture des prélèvements en France, Conseil d'Analyse Economique, Paris.

Card, David, 1995, "The Wage Curve: A Review," Journal of Economic Literature, 33(2):78599 , June.

Daveri, Francesco and Tabellini, Guido, 2000, "Unemployment, Growth and Taxation in Industrial Countries," Economic Policy, pp. 49-104, April.

Decressin, Jorg, Marcello Estevão, Phillip Gerson, and Christopher Klingen, 2001, "Job-Rich Growth in Europe," in Selected Euro-Area Countries: Rules-Based Fiscal Policy and JobRich Growth in France, Germany, Italy and Spain, Chapter III, Washington, DC, IMF, webpage; http://www.imf.org/external/pubs/ft/scr/2001/cr01203.pdf. 
Gianella, Christian, 2000, "Local Unemployment and Wages," Working Paper, INSEE, November.

Laroque, Guy and Salanié, Bernard, 2000, "Une décomposition du non-emploi en France," Economie et Statistique, INSEE, 331(1):47-66.

_-_. 1999, "Prélèvement ct transferts sociaux: une analyse descriptive des incitations financières au travail," Économie et Statistique, 328(8):3-20.

Layard, R., S. Nickell, and R. Jackman, 1991, Unemployment, Oxford: Oxford University Press.

Nickell, S., 1981, "Biases in Dynamic Models with Fixed Effects," Econometrica, 49(6):1417-26, November. , and R. Layard, 1997, "Labour Market Institutions and Economic Performance," Working Paper, Oxford : Institute of Economics and Statistics, Oxford University.

Moulton, Brent R., 1990, "An Illustration of a Pitfall in Estimating the Effects of Aggregate Variables on Micro Units," Review of Economics and Statistics, 72(2):334-38, May.

— 1986 , "Random Group Effects and the Precision of Regression Estimates," Journal of Econometrics, 32(3):385-97, August.

OECD, 1999a, Benefits Systems and Work Incentives, OECD, Paris.

- $1999 \mathrm{~b}$, Employment Outlook, OECD, Paris.

, 2001, Employment Outlook, OECD, Paris.

Pisani-Ferry, J., 2000, Plein Emploi, Conseil d'Analyse Economique, Paris. 